\title{
KONSEP SYARIAH PADA PEMBIAYAAN JAMINAN SERTIFIKASI DAN DAMPAKNYA TERHADAP MANAJEMEN RISIKO (Studi Kasus Pada BPR Syariah Di Kota Mataram)
}

\author{
Isnawati \\ Fakultas Ekonomi dan Bisnis Unram \\ Isnawati.isna@unram.ac.id \\ Muttaqillah \\ Fakultas Ekonomi dan Bisnis Unram \\ Siti Sofiyah \\ Fakultas Ekonomi dan Bisnis Unram
}

\begin{abstract}
All Islamic banking products must adhere to existing Islamic principles, including financing products with guaranteed Educator Certificates. Considering that this product is issued by all Sharia and conventional BPRs with almost the same mechanism of lending, starting from the type of guarantee and the amount of the installments. Therefore this paper aims to review more about the sharia concept contained in the financing product with the guarantee of the educator's certificate, as well as how the impact on banking risk management. This research is a social research with a type of descriptive research that is explored using an approach method based on banking regulation such as Bank Indonesia regulations, besides that it also uses principles / concepts in Islamic law. And the results of the study explain that there is still a lack of clarity on the concept of Sharia financing products with guaranteed educator certificates. Because Islamic banking products must remain guided by Islamic shari'ah, among others, they do not contain elements of maysir, Gharar, Riba, and their business sector must be halal. If tracing on one of the available evidence and based on the observation of the researcher, it can be concluded that this product has fully contained the Sharia concept, because this product has not been able to avoid the element of maysir, ghrarar, and the transaction halal element is still in doubt. This type of product can be said to have a high level of risk if you look at the financing mechanism, but based on the NPL data owned by BPRS X, it does not succeed in proving that a high level of income will be followed by a high level of risk.
\end{abstract}

\section{Keywords; Sharia, Maysir, Gharar, Riba}




\begin{abstract}
Abstrak
Semua produk perbankan syariah harus menganut prinsip-prinsip syariah yang ada, tidak terkecuali pada produk pembiayaan dengan jaminan Sertikat Pendidik. Mengingat produk ini dikeluarkan oleh semua BPR baik yang syariah maupun yang konvensional dengan mekanisme pemberian kredit yang hampir sama, mulai dari jenis jaminannya maupun besaran angsurannya. Oleh karena itu tulisan ini bertujuan untuk meninjau lebih dalam konsep syariah yang terdapat dalam produk pembiayaan dengan jaminan sertifikat pendidik tersebut, serta bagaimana dampaknya terhadap manajemen risiko perbankan dengan system angsuran yang mengandalkan saat pencairan sertifikasi yang sebagian besar tidak rutin setiap bulannya. Penelitian ini merupakan penelitian social dengan jenis penelitian deskriptif yang digali dengan menggunakan metode pendekatan yang berdasar pada ketentuan peraturan perbankan seperti Surat Edaran Bank Indonesia, selain itu juga menggunakan asas-asas/ prinsip/konsep dalam hukum Islam terutama tentang mekanisme menjalankan perbankan syariah yang mendasarkan kerjanya pada prinsip hukum Islam. Yaitu penelitian ini tidak hanya mengacu pada peraturan perbankan, namun juga menggunakan pendekatan Konseptual (conceptual approach), yaitu mengacu pada konsep hukum Islam serta pandangan-pandangan para pakar hukum Islam tentang perbankan syariah. Dan hasil penelitian menjelaskan bahwa masih terdapat ketidak jelasan konsep Syariah pada produk pembiayaan dengan jaminan sertifikat pendidik. Karena produk perbankan Syariah harus tetap berpedoman pada syari'ah Islam, antara lain tidak mengandung unsur maysir, Gharar, riba, serta bidang usahanya harus halal. Jika menelusuri pada salah satu bukti yang ada dan berdasarkan hasil observasi peneliti, maka dapat disimpulkan bahwa produk ini sudah sepenuhnya memuat konsep Syariah, karena produk ini belum mampu terhindar dari unsur maysir, ghrarar secara $100 \%$, maupun unsur kehalalan transaksinya masih diragukan. Jenis produk ini bisa dikatakan memiliki tingkat risiko yang tinggi jika melihat mekanisme pembiayaannya, namun berdasarkan data NPL yang dimiliki BPRS $X$ tersebut, tidak berhasil membuktikan bahwa tingkat pendapatan yang tinggi akan diikuti oleh tingkat risiko yang tinggi pula.
\end{abstract}

\title{
Kata Kunci : Syariah, Maysir, Gharar, Riba
}




\section{PENDAHULUAN}

Begitu dinamisnya perkembangan industri perbankan syariah di Indonesia. terdapat beberapa faktor pendorong yang mendukungnya, salah satu faktor pendorong tersebut menurut Deputi Gubernur Bank Indonesia, Halim Alasmsyah, adalah adanya beberapa produk perundangan yang memberikan kepastian hukum dan meningkatkan aktivitas pasar keuangan syariah, seperti: (i) UU No.21 tahun 2008 tentang Perbankan Syariah; (ii) UU No.19 tahun 2008 tentang Surat Berharga syariah Negara (sukuk); dan (iii) UU No. 42 tahun 2009 tentang Amandemen Ketiga UU No.8 tahun 1983 tentang PPN Barang dan Jasa. Lahirnya UU Perbankan syariah mendorong peningkatan jumlah BUS dari sebanyak 5 BUS menjadi 11 BUS dalam kurun waktu kurang dari dua tahun (2009-2010).

Dengan semakin besarnya perhatian dan dukungan pemerintah terhadap perkembangan lembaga keuangan syariah maka bukan tidak mungkin lembaga keuangan syariah tidak hanya sekedar menjadi pilihan alternatif bagi masyarakat yang membutuhkan layanan perbankan atau pembiayaan berbasis syariah tetapi dapat menjadi pilihan utama. Pendapat ini bukan tanpa dasar mengingat Indonesia merupakan negara dengan jumlah penduduk muslim terbesar di dunia. Namun terlepas dari argumentasi tersebut, 
Isnawati, Muttaqillah, $\mathcal{E}$ Siti Sofiyah : Konsep Syariah pada Pembiayaan Jaminan ...

apabila mencermati pola perkembangan yang terjadi sampai saat ini dimana keberadaan lembaga keuangan syariah begitu banyak jumlahnya dalam berbagai skala tingkatan pelayanan dan hampir tersebar di semua wilayah Indonesia maka ada satu hal yang tetap perlu menjadi perhatian dan pertanyaan mendasar adalah apakah perbankan dan unit-unit pembiayaan syariah tersebut telah menerapkan prinsip syariah secara benar. Hal ini setidaknya menjadi dasar perenungan awal atau kasar mengingat masih cukup banyak bank yang memiliki unit layanan perbankan syariah tetapi bisnis intinya tetap mengandalkan layanan perbankan konvensional (non syariah). Karenanya atas kondisi ini sejumlah pihak mempertanyakan dinamika perkembangan perbankan syariah di Indonesia yang begitu menggairahkan ini sebenarnya lebih merupakan fenomena apa ?, terlebih lagi belakangan ini munculnya berbagai produk pembiayaan di BPR Syariah yang mana produk ini juga ditemukan pada BPR Konvensional seperti Kredit/pembiayaan dengan Jaminan Sertifikat Pendidik.

Jika menelaah lebih dalam pada penjelasan Pasal 8 UU Perbankan bahwa dalam penjelasan tersebut menjelaskan agunan hanya dapat berupa barang atau benda, proyek, atau hal tagih yang dibiayai dengan kredit yang bersangkutan. Benda menurut ketentuan Pasal 499 BW adalah tiap-tiap barang dan dan tiap-tiap hak yang dapat dikuasai oleh hak milik. Sedangkan dalam 
ilmu hokum, pengertian benda lebih luas, yaitu segala sesuatu yyang dapat menjadi objek hokum dan barang-barang yang dapat menjadi milik serta hak setiap orang yang dilindungi oleh hukum.

Pada praktiknya dalam dunia perbankan beserta perkembangannya, terdapat berbagai macam jenis benda yang dijadikan jaminan kredit, seperti yang dilakukan beberapa bank khususnya Bank Perkreditan rakyat (BPR) saatsaat ini memiliki sebuah produk kredit / pembiayaan bagi Bank Pembiayaan Rakyat (BPR) Syariah dengan jaminan sertifikat pendidik. Mekanisme penjaminan Sertifikat Pendidik dalam prakteknya adalah ketika debitur mengajukan permohonan kredit kepada bank, maka sertifikat Pendidik milik debitur dipergunakan sebagai objek jaminan dan ditahan oleh bank selaku kreditur. Metode cicilan pembayarannya adalah pada setiap tunjangan sertifikasi dari debitur tersebut cair, seketika tunjangan tersebut dipotong oleh bank guna membayar cicilan. Hampir semua BPR mengeluarkan jenis produk pembiayaan dengan jaminan sertifikat pendidik ini, tidak terkecuali BPR Syariah.

Semua produk perbankan syariah harus menganut prinsip-prinsip syariah yang ada, tidak terkecuali pada produk pembiayaan dengan jaminan Sertikat Pendidik. Mengingat produk ini dikeluarkan oleh semua BPR baik yang syariah maupun yang konvensional dengan mekanisme pemberian kredit yang 
Isnawati, Muttaqillah, \& Siti Sofiyah : Konsep Syariah pada Pembiayaan Jaminan ...

hampir sama, mulai dari jenis jaminannya maupun besaran angsurannya. Berikut adalah gambaran simulasi besaran angsuran pembiayaan jaminan Sertifikat Pendidik pada salah satu BPR Syariah dan BPR Konvensional yang ada di Kota Mataram.

Oleh karena itu tulisan ini bertujuan untuk meninjau lebih dalam konsep syariah yang terdapat dalam produk pembiayaan dengan jaminan sertifikat pendidik tersebut, serta bagaimana dampaknya terhadap manajemen risiko perbankan dengan system angsuran yang mengandalkan saat pencairan sertifikasi yang sebagian besar tidak rutin setiap bulannya. Sera dampaknya terhadap manajemen risiko khususnya risiko kredit/pembiayaan. Sehingga nantinya manfaat dari penelitian ini diharapkan dapat dijadikan sebagai bahan evaluasi bagi perbankan maupun bagi pihak regulator dalam hal ini Bank Indonesia untuk melihat kembali sejauh mana produk-produk yang dikeluarkan memenuhi prinsip-prinsip Syariah Islam.

\section{TELAAH LITERATUR}

\section{Konsep dan Prinsip Dasar Ekonomi Islam}

Agama Islam memiliki konsepsi nilai sebagai dasar kebenaran yang mengatur semua bidang kehidupan manusia secara komprehensif dan 
universal, baik itu dalam hubungan vertikal dengan Sang Pencipta ( $h a b /$ min Allāh) maupun hubungan secara horizontal sesama manusia ( habl min an-nās). Adapun tiga nilai dalam ajaran Islam tersebut meliputi :

1. Akidah: komponen ajaran Islam yang mengatur tentang keyakinan atas keberadaan dan kekuasaan Allah sehingga harus menjadi keimanan seorang muslim manakala melakukan berbagai aktivitas dimuka bumi semata-mata untuk mendapatkan keridlaan Allah sebagai khalifah yang mendapat amanah dari Allah.

2. Syariah: komponen ajaran Islam yang mengatur tentang kehidupan seorang muslim baik dalam bidang ibadah (habluminAllah) maupun dalam bidang muamalah(hablumminannas) yang merupakan aktualisasi dari akidah yang menjadi keyakinannya. Sedangkan muamalah sendiri meliputi berbagai bidang kehidupan antara lain yang menyangkut ekonomi atau harta dan perniagaan disebut muamalah maliyah.

3. Akhlak: landasan perilaku dan kepribadian yang akan mencirikan dirinya sebagai seorang muslim yang taat berdasarkan syariah dan aqidah yang menjadi pedoman hidupnya sehingga disebut memiliki akhlaqul karimah sebagaimana hadis Nabi saw yang menyatakan, "Tidaklah aku diutus kecuali untuk untuk menyempurnakan akhlak mulia". 
Isnawati, Muttaqillah, \& Siti Sofiyah : Konsep Syariah pada Pembiayaan Jaminan ...

Dari ketiga nilai tersebut, di dalam Islam terdapat cukup banyak ketentuan yang menjadi acuan dalam melakukan kegiatan ekonomi antara lain meliputi sebagai berikut:2

- Islam menempatkan fungsi uang semata-mata sebagai alat tukar, bukan sebagai komoditas yang diperdagangkan apalagi untuk kegiatan spekulatif.

- Riba dalam segala bentuknya dilarang bahkan dalam ayat al-Qur'an tentang pelarangan riba yang terakhir yaitu surah al-Baqarah [2]:278279 secara tegas dinyatakan sebagai berikut: "Hai orang-orang yang beriman takutlah kepada Allah dan tinggalkanlah sisa-sisa riba itu jika kamu orang beriman. Kalau kamu tiada memperbuatnya ketahuilah ada peperangan dari Allah dan RasulNya terhadapmu dan jika kamu bertobat maka untukmu pokok-pokok hartamu. kamu tidak menganiaya dan tidak pula teraniaya."

- Harta harus berputar (diniagakan) sehingga tidak boleh hanya berpusat pada segelintir orang dan Allah sangat tidak suka terhadap orang yang menimbun harta sehingga tidak produktif dan oleh karenanya bagi mereka yang mempunyai harta yang tidak produktif akan dikenakan zakat yang lebih besar dibanding jika diproduktifkan. Hal ini juga dilandasi ajaran yang menyatakan bahwa kedudukan manusia dibumi 
sebagai khalifah yang menerima amanah dari Allah sebagai pemilik mutlak segala yang terkandung didalam bumi dan tugas manusia untuk menjadikannya sebesar-besar kemakmuran dan kesejahteraan manusia.

- Bekerja dan atau mencari nafkah adalah ibadah dan waJib dilakukan sehingga tidak seorangpun tanpa bekerja -yang berarti siap menghadapi resiko- dapat memperoleh keuntungan atau manfaat (bandingkan dengan perolehan bunga bank dari deposito yang bersifat tetap dan hampir tanpa resiko).

- Dalam berbagai bidang kehidupan termasuk dalam kegiatan ekonomi harus dilakukan secara transparan dan adil atas dasar suka sama suka tanpa paksaan dari pihak manapun.

\section{Fungsi Bank Dalam Prinsip Syariah}

Fungsi Bank dalam konsepsi syariah menurut Muhamad Syafi'i Antonio meliputi: fungsi bank syariah sebagai manajemen investasi, fungsi bank syariah sebagai investasi, fungsi bank syariah sebagai jasa-jasa keuangan, dan fungsi bank syariah sebagai jasa sosial.3 Keempat fungsi bank tersebut diatas apabila diuraikan secara operasional adalah : 
Isnawati, Muttaqillah, \& Siti Sofiyah : Konsep Syariah pada Pembiayaan Jaminan ...

- Sebagai penerima amanah untuk melakukan investasi atas dana-dana yang dipercayakan oleh pemegang rekening investasi/deposan atas dasar prinsip bagi hasil sesuai dengan kebijakan investasi bank.

- Sebagai pengelola investasi atas dana yang dimiliki oleh pemilik dana/sahibul mal sesuai dengan arahan investasi yang dikehendaki oleh pemilik dana (dalam hal ini bank bertindak sebagai manajer investasi)

- Sebagai penyedia jasa lalu lintas pembayaran dan jasa-jasa lainnya sepanjang tidak bertentangan dengan prinsip syariah

- Sebagai pengelola fungsi sosial seperti pengelolaan dana zakat dan penerimaan serta penyaluran dana kebajikan (fungsi optional)

\section{Aspek Kelembagaan Bank Dalam Prinsip Syariah}

Pengertian syariah (UU No. 10/1998) adalah aturan perjanjian berdasarkan hukum Islam antara bank dan pihak lain untuk penyimpanan dana dan atau pembiayaan kegiatan usaha atau kegiatan lainnya yang dinyatakan sesuai dengan syariah. Sedangkan perbankan syariah adalah sistem pelayanan perbankan yang berdasarkan syariah (hukum) Islam. Dimana untuk memulainya perlu dilandasi sebuah kesepakatan (akad) yang merupakan keterikatan antara bank syariah dan nasabahnya yang merupakan dasar untuk melakukan transaksi di bank syariah. Akad keterikatan yang dimaksud dalam prinsip syariah disini adalah menempatkan posisi bank syariah dan nasabah 
bank syariah dalam relasi azas kemitraan, keadilan, dan transparan, bukan relasi antara peminjam dan pemberi pinjaman. Selanjutnya berangkat dari prinsip ekonomi berdasarkan Islam dan azas kemitraan maka transaksi perbankan syariah harus memenuhi sejumlah unsur sebagai berikut :

1. Tidak mengandung unsur riba.

2. Tidak mengenal konsep "time-value of money"

3. Tidak memiliki potensi mencelakai/membahayakan pihak lain maupun diri sendiri,

4. Tidak ada unsur penipuan ( $g h a r a ̄ r)$

5. Tidak ada unsur judi (maisir).

\section{Prinsip Produk Layanan Perbankan Syariah}

Secara umum produk jasa layanan perbankan terdiri atas kegiatan penghimpunan dana dan penyaluran dana (kredit). Hal yang sama juga dilakukan oleh bank syariah dimana terdapat produk giro, tabungan dan deposito untuk layanan simpanan dan produk pembiayaan untuk layanan penyaluran dana. Perbedaan mendasar produk-produk layanan perbankan syariah bila dibandingkan dengan bank konvensional adalah terletak pada prinsip ketentuan yang ditetapkan.

Dalam sistem syariah kegiatan penghimpunan dana menerapkan prinsip Wadiah dan pinsip Mudharabah. Sementara untuk penyaluran dana menganut 
prinsip jual Beli dan prinsip Bagi Hasil. Uraian analisa dari prinsip-prinsip produk layanan perbankan syariah adalah sebagai berikut.

\section{a) Penghimpunan Dana}

1. Prinsip Wadīah dalam produk giro dan tabungan adalah akad titipan murni dari pihak pemilik barang/dana kepada pihak penerima kepercayaan untuk menjaga keselamatan, keamanan dan keutuhan.

2. Prinsip Mudhārabah dalam produk tabungan dan deposito adalah akad penyimpanan dana dengan nisbah yang disepakati pada awal akad untuk bagi hasilnya.

\section{b) Penyaluran Dana}

\section{Prinsip Jual Beli}

Pengertian prinsip Jual Beli di sini menekankan bahwa dalam perbankan syariah mengandung beberapa kebaikan, antara lain tujuan pembiayaan selalu diberikan kepada sektor riil karena yang menjadi dasar nilai adalah barang yang diperjual-belikan. Begitu juga dengan harga yang disepakati tidak berubah/tetap sampai akhir akad. Jenis prinsip jual beli terdiri atas Murābahah, Salam dan Istishnā'. 


\section{\# Murābahah}

Adalah akad jual beli barang tertentu antara penjual dan pembeli dimana dalam transaksi jual beli tersebut penjual menyebutkan jenis barang yang akan dijual termasuk harga pembelian ditambah keuntungan yang diambil penjual Murābahah dapat dilakukan secara tunai dan secara angsuran.

\section{\# Salam}

Adalah pembelian barang dengan penyerahan dilakukan kemudian setelah ada pembayaran di awal. Secara operasional prinsip salam adalah : (1) akad jual beli barang pesanan ( muslam fih) antara pembeli (muslam) dengan penjual (muslam ilaih), (2) spesifikasi (jenis, macam ukuran, jumlah, mutu) dan harga barang disepakati diawal akad dan pembayaran dilakukan dimuka secara penuh, (3) apabila bank bertindak sebagai pembeli, kemudian memesan kepada pihak lain untuk menyediakan barang (Salam Paralel). Produk layanan perbankan syariah dengan prinsip Salam adalah untuk produksi agribisnis atau industri sejenis lainnya.

\section{\# Istishna}


Adalah akad pembelian barang melalui pesanan dan diperlukan proses untuk pembuatannya sesuai dengan pesanan pembeli dan pembayaran dilakukan di muka sekaligus atau secara bertahap. Jadi perbedaan dengan Salam hanya pada metode pembayarannya. Salam pembayarannya harus dimuka sedangkan Istișna tidak harus di muka.

\section{Prinsip Bagi Hasil}

Adalah akad bersama kegiatan usaha yang didalamnya diperjanjikan adanya pembagian hasil atas keuntungan yang akan didapat antara kedua belah pihak atau lebih. Jenis bagi hasil terdiri atas Mudhārabah dan Musyarakah.

\section{\# Mudhārabah}

Akad antara pemilik modal dan pengelola modal untuk memperoleh keuntungan dengan kesepakatan bahwa pembagian hasil keuntungan dibagi sesuai nisbah yang disepakati awal akad. Prinsip pembagian hasil usaha adalah revenue sharing atau profit sharing. Secara operasional pemilik modal di sini adalah bank dan pengelola modal adalah nasabah. 


\section{\# Musyārakah}

Akad untuk usaha patungan untuk membiayai usaha yang halal dan produktif. Pembayaran kembali atas dana dari pihak-pihak yang terlibat dalam pembiayaan proyek tersebut berikut bagi hasil yang disepakati dapat dilakukan secara bertahap ataupun sekaligus setelah proyek selesai. Produk layanan perbankan syariah yang sesuai prinsip musyārakah adalah pembiayaan proyek.

\section{Prinsip-prinsip pada Bank Syariah}

\section{Prinsip Al-Ta'awun}

Merupakan prinsip untuk saling membantu dan bekerja sama. Dalam hal ini Allah Swt telah memerintahkan kepada manusia untuk berbuat saling tolong menolong dalam berbuat kebaikan dan takwa.

\section{Prinsip Menghidar Al-Ikhtinaz}

Prinsip ini sejalan dengan fungsi uang, yaitu tidak membiarkan uang menganggur dan tidak berputar dalam transaksi yang bermanfaat bagi masyarakat umum.

Dalam perbankan Syariah dilarang keras untuk melakukan transaksi apabila terdapat hal-hal sebagai berikut: 
Isnawati, Muttaqillah, \& Siti Sofiyah: Konsep Syariah pada Pembiayaan Jaminan ...

a. Gharar, yaitu adanya unsur-unsur ketidakpastian atau tipu muslihat dalam transaksi.

b. Maysir, yaitu unsur judi yang transaksinya bersifat spekulatif yang dapat menimbulkan kerugian satu pihak dan keuntungan bagi pihak lain.

c. Riba, yaitu transaksi yang menggunakan sistem bunga.

\section{Landasan Hukum Sertifikat Pendidik}

Mengacu pada Pasal 1 angka 12 UU Guru dan Dosen, Sertifikat Pendidik adalah bukti formal sebagai pengakuan yang diberikan kepada guru dan dosen sebagai tenaga professional melalui proses sertifikasi guru. Definisi Guru seperti yang dijelaskan dalam UU Guru dan Dosen adalah pendidik professional dengan tugas utama mendidik, mengajar, membimbing, mengarahkan, melatih, menilai dan mengevaluasi peserta didik pada pendidikan anak usia dini jalur pendidikan formal, pendidikan dasar, dan penndidikan menengah. Sedangkan Dosen adalah pendidik professional dan ilmuwan dengan tugas utama mentransformasikan, mengembangkan, dan menyebarluaskan ilmu pengetahuan, teknologi, dan seni melalui pendidikan, penelitian, dan pengabdian kepada masyarakat. Arti professional sendiri seperti yang diartikan dalam pasal 1 angka 4 UU Guru dan Dosen adalah suatu pekerjaan atau kegiatan yang dilakukan oleh seseorang dan menjadi sumber penghasilan kehidupan yang memerlukan keahlian, kemahiran, atau kecakapan yang 
memenuhi standar mutu atau norma tertentu serta memerlukan pendidikan profesi.

\section{Risiko}

Definisi risiko disimpulakn yaitu merupakan sesuatu hal yang kemungkinan terjadinya kerugian yang tidak diduga atau tidak diinginkan.Sedangkan risiko bank menurut Tampubolon (2004), yaitu kombinasi dari tingkat kemungkinan sebuah peristiwa terjadi disertai konsekuensi dari peristiwa tersebut pada bank.Dengan demikian risiko mempunyai dua karakteristik yaitu:

1. Ketidakpastian atas terjadinya suatu peristiwa

2. Ketidakpastian yang bila terjadi akan menimbulkan kerugian

Menurut Peraturan Bank Indonesia No. 13/25/PBI/2011 tentang penerapam manajemen risiko bagi BUS dan UUS.Risiko adalah potensi kerugian akibat terjadinya suatu peristiwatertentu, risiko kerugian yaitu kerugian yang terjadi sebagai konsekuensi langsung atau tidak langsung dari kejadian risiko, dimana kerugian ini bisa dalam bentuk keuangan maupun non keuangan.

\section{Manajemen Risiko Bank}

Penerapan manajemen risiko di bank syariah wajib disesuaikan den gan tujuan, kebijakan, usaha, ukuran, dan kompleksitas usaha dan kemampuan 
Isnawati, Muttaqillah, E Siti Sofiyah : Konsep Syariah pada Pembiayaan Jaminan ...

bank. Penerapan manajemen risiko diatur dalam PBI No. 13/23/PBI/2011. Berikut jenis-jenis risiko pada perbankan syariah menurut PBI No. 13/23/PBI/2011, yaitu: 1)Risiko kredit ;2) Risiko pasar; 3) Risiko likuiditas; 4)

Risiko operasional; 5) Risiko hokum; 6) Risiko reputasi; 7) Risiko strategis; 8) Risiko kepatuhan

\section{* RisikoKredit}

Risiko kredit adalah risiko akibat kegagalan nasabah atau pihak lain dalammemenuhi kewajiban kepada bank sesuai denagn perjanjian yang disepakati. Syariah membedakan antara dua jenis gagal bayar, yaitu yang mampu (gagal bayar sengaja) dan gagal bayar karena bangkrut (tidak mampu membayar kembali utangnya karena alasan-alasan yang diakui syariah). Salah satu yang termasuk risiko kredit adalah risiko konsentrasi pembiayaan. Risiko ini timbul akibat terkonsentrasinya penyediaan dana kepada satu pihak atau sekelompok pihak, industri, sector, dan area geografis (Rustam, 2013). Risiko kredit bersumber dari berbagai aktivitas bisnis bank, baik pembiayaan maupun berbagai instrument keuangan lain seperti surat berharga, akseptasi, transaksi antar bank,transaksi pembiayaan perdagangan, transaksi nilai tukar, derivatif serta kewajiban komitmen dan kontigensi. Berikut disajikan jenis pembiayaan pada bank syariah dan risiko yang ditimbulkannya: 


\section{- Murabahah}

Pembiayaan dalam jangka panjang menimbulkan risiko tidak bersaing bagi hasil kepada dana pihak ketiga Ijarah Bila barang yang disewakan milik bank, risikonya adalah tidakproduktifnya asset ijarah karena tidak adanya nasabah. Bila barang yang disewakan bukan milik bank, risikonya adalah rusaknya barang oleh nasabah di luar pemakaian normal. Oleh karena itu, diperlukan kovenan ganti rugi kerusakan barang yang tidak disebabkan oleh pemakaian normal. Bila diberikan dalam bentuk jasa risikonya adalah tidak performmya pemberi jasa. Oleh karena itu, diperlukan kovenan risiko itu merupakan tanggung jawab nasabah karena pemberi jasa dipilih oleh nasabah sendiri.

- Ijarah MuntahiyyaBittamlik

Bila pembayaran dengan ballon payment, yakni pembayaran angsuran besar pada akhir periode risikonya adalah risiko ketidakmampuan nasabah untuk membayarnya. Risiko ini dapat diatasi dengan memperpanjang jangka waktu sewa.

- Salam dan Istishna

Risiko gagal serah barang dan risiko jatuhnya harga barang. Sumber: Adiwarman Karim dalam Rustam (2013) Berdasarkan tabel di atas dapat dikatakan bahwa bank syariah harus mampumengelola risiko piutang 
$\underline{\text { Isnawati, Muttaqillah, E Siti Sofiyah : Konsep Syariah pada Pembiayaan Jaminan ... }}$

murabahah, ijarah, salam, isthisna, muhdarabah dan musyarakah. Bank harus mampu mengelola risiko kredit dalam portofolio pembiayaan terkait kemungkinan default, penurunan kualitas dan konsentrasi.

Berikut hal-hal yang berkaitan dengan proses manajemen risiko kredit di bank syariah:

1. Bank syariah harus mempertimbangkan risiko kegagalan mitra dalam memenuhi kewajiban pembayaran angsuran dan/atau penyerahan asset.

2. Masing-masing jenis instrument pembiyaan mempunyai karakteristik yang unik, maka untuk kontrak yang tidak mengingat (waad) juga harus dipertimbangkan akan munculnya risiko kredit yang dinilai terpisah.

3. Bank syariah harus mempertimbangkan jenis risiko lain yang menimbulkan risiko kredit.

4. Bank syariah dilarang memberikan/memaksakan tambahan margin/denda jika nasabah terlambat membayar kewajiban.

\section{METODE PENELITIAN}

\section{Jenis Penelitian}

Penelitian ini merupakan penelitian social dengan jenis penelitian deskriptif yang digali dengan menggunakan metode pendekatan yang berdasar 
pada ketentuan peraturan perbankan seperti Surat Edaran Bank Indonesia, selain itu juga menggunakan asas-asas/ prinsip/konsep dalam hukum Islam terutama tentang mekanisme menjalankan perbankan syariah yang mendasarkan kerjanya pada prinsip hukum Islam. Yaitu penelitian ini tidak hanya mengacu pada peraturan perbankan, namun juga menggunakan pendekatan Konseptual (conceptual approach), yaitu mengacu pada konsep hukum Islam serta pandangan-pandangan para pakar hukum Islam tentang perbankan syariah.

\section{Jenis dan Sumber Data Penelitian}

Data yang digunakan dalam penelitian ini adalah data Data Kualitatif dan data Kuantitatif. Data Kualitatif berupa data-data yang berifat informasi dan tidak mengandung unsur angka-angka seperti mekanisme pelaksanaan Kredit / Pembiayaan Jaminan sertifikasi pada BPR di Kota Mataram. Sedangkan data kuantitatif merupakan data angka-angka seperti data Laporan Keuangan BPR Syariah di Kota Mataram. Sumber data penelitian diperoleh dari data primer dan data sekunder. Data primer diperoleh langsung dari Lokasi Penelitian dengan melakukan wawancara langsung ke sumber informasi untuk menggali informasi yang dibutuhkan. Sedangkan data sekunder diperoleh melalui data yang sudah dikomentasikan oleh pihak BPR sendiri maupun pihak 
Isnawati, Muttaqillah, \& Siti Sofiyah: Konsep Syariah pada Pembiayaan Jaminan ...

ke tiga seperti melalui web (situs) tiap BPR syariah di Kota Mataram untuk menelususri data-data yang dibutuhkan dalam penelitian ini.

\section{Teknik Pengumpulan Data Penelitian}

Prosedur / teknik pengumpulan data penelitian dilakukan dengan teknik wawancara untuk menggali beberapa informasi yang sifatnya kualitatif seperti mekanisme pembiayaan Jaminan Sertifikat Pendidik pada BPR syariah di Kota Mataram. Selain teknik wawancara, pengumpulan data penelitian juga dilakukan dengan metode penelusuran web (situs) dari tiap BPR syariah di Kota Mataram untuk menelususri data-data sekunder yang dibuutuhkan dalam penelitian ini. Lokasi penelitian dilakukan di Kota Mataram, khususnya di salah satu BPR syariah yang ada di Kota Mataram yaitu BPRS X yang mengeluarkan produk Kredit/Pembiayaan dengan jaminan Sertifikat Pendidik tersebut.

\section{Definisi Operasional Variabel Penelitian}

Selain menjawab permasalah penelitan dengan menggunakan metode pendekatan konsep danperaturan Perbankan. pada penelitan ini juga ingin mengetahui dampak dari adanya kredit jaminan sertifikasi ini terhadap Manajemen Risiko perbankan, khusunya Risiko Kreditnya. Maka untuk tujuan penelitian tersebut, maka digunakan variabel Risiko Kredit / kualitas penyediaan dana yang diukur dengan indikator sebagai beriku:

$$
B=\frac{\text { Pembiayaan Bermasalah }}{\text { Total Pembiayaan }}
$$


Keterangan:

- B adalah kualitas penyediaan dana.

- Pembiayaan bermasalah adalah pembiayaan pada pihak ketiga bukan bank

- Total Pembiayaan adalah total pembiayaan sebelum dikurangi cadangan kerugian penurunan nilai.

\section{Teknik Analisis Data Penelitian}

Berdasarkan tema penelitian yang dilakukan, maka model analisis yang akan dilakukan dalam penelitian ini adalah Metode Analisis Deskriptif Kualitatif, yaitu metode analisa yang melakukan pendekatan analisis dengan menggunakan sudut pandang peneliti sebagai tool analisis utama. Pada metode analisis ini hasil eksplorasi dipaparkan atau dideskripsikan untuk menjawab rumusan masalah penelitian. Analisis data juga akan dilengkapi dengan data lain untuk mendapatkan hasil yang lebih komprehensif.

\section{HASIL PENELITIAN DAN PEMBAHASAN}

\section{Deskripsi Data Penelitian}

Berikut gambaran data Rata-rata jumlah piutang dan pembiayaan serta rata-rata jumlah pembiayaan bermasalah yang ada pada salah satu BPRS X di Kota Mataram sejak tahun 2011 sampai dengan tahun 2017. 
Isnawati, Muttaqillah, \& Siti Sofiyah : Konsep Syariah pada Pembiayaan Jaminan ...

Tabel 1

Rerata Jumlah Piutang dan Pembiayaan, Pembiayaan Bermasalah, NPL Tahun 2011 s/d 2017.

\begin{tabular}{|c|c|c|c|c|c|}
\hline Tahun & $\begin{array}{c}\text { Jml.Pembiayaa } \\
\mathrm{n}\end{array}$ & $\begin{array}{c}\text { Jml.Pembiayaa } \\
\text { n Bermasalah }\end{array}$ & NPL & $\begin{array}{l}\text { Rerata } \\
\text { NPL }\end{array}$ & $\begin{array}{r}\text { Peningkata } \\
\mathrm{n}\end{array}$ \\
\hline 2017 & $203,182,121$ & $1,872,357$ & 0.0092 & 0.0092 & \multirow{7}{*}{0.0005} \\
\hline 2016 & $117,297,818$ & 948,953 & 0.0081 & \multirow{6}{*}{0.0087} & \\
\hline 2015 & $97,171,408$ & 809,504 & 0.0083 & & \\
\hline 2014 & $71,446,125$ & 636,825 & 0.0089 & & \\
\hline 2013 & $55,071,005$ & 530,650 & 0.0096 & & \\
\hline 2012 & $49,187,695$ & 452,167 & 0.0092 & & \\
\hline 2011 & $40,199,602$ & 332,240 & 0.0083 & & \\
\hline
\end{tabular}

Sumber : Data diolah

Berikut adalah rincian jumlah piutang dan pembiayaan yang ada pada

BPR X pada tahun 2011 sampai dengan 2017:

Tabel 2

Rincian Piutang dan pembiayaan di BPR Syariah X Kota Mataram

Tahun 2011 s/d 2017

\begin{tabular}{|c|c|c|c|c|c|c|c|c|}
\hline \multirow{2}{*}{ Periode } & \multicolumn{7}{|c|}{ Jumlah Piutang dan Pembiayaan (Dalam Ribuan Rupiah) } \\
\cline { 2 - 9 } & Murabahah & Salam & Istishna' & Mudharabah & Musyarakah & Ijarah & Qardh & Multijasa \\
\hline 2017 & $186,231,951$ & - & - & $7,579,000$ & $2,961,713$ & - & $6,359,457$ & 50,000 \\
\hline 2016 & $102,219,552$ & - & - & $9,718,000$ & 156,422 & - & $5,003,844$ & 200,000 \\
\hline 2015 & $88,482,653$ & - & - & $4,831,250$ & 167,531 & - & $3,439,974$ & 250,000 \\
\hline 2014 & $66,247,409$ & - & - & $1,975,000$ & 177,313 & - & $2,846,403$ & 200,000 \\
\hline 2013 & $53,128,196$ & - & - & - & - & - & $1,892,809$ & 50,000 \\
\hline 2012 & $46,874,384$ & - & - & 137,493 & 175,000 & - & $1,840,963$ & 159,855 \\
\hline 2011 & $38,290,772$ & - & - & 85,277 & 350,000 & - & $1,234,887$ & 238,667 \\
\hline
\end{tabular}

Sumber : Lampiran 


\section{Hasil dan Pembahasan}

\section{Konsep Syariah pada Kredit / Pembiayaan dengan Jaminan Sertifikat}

\section{Pendidik pada BPR Syariah di Kota Mataram.}

BPR (Bank Pembiayaan Rakyat) X merupakan salah satu BPR Syariah

di Kota Mataram yang juga memiliki produk pembiayaan jaminan sertifikat pendidik. Produk ini mulai dibula pada Tahun 2016. Dan sebagaimana yang dijelaskan pada latar belakang bahwa produk pembiayaan ini juga dimiliki oleh BPR (Bank Perkreditan Rakyat) yang merupakan bank konvensional. Sepintas tidak terlihat perbedaan jenis produk ini pada Bank Perkreditan rakyat dan Bank Pembiayaan Rakyat, mengingat jumlah angsuran yang relative sama di kedua bank tersebut untuk produk yang sejenis tersebut. Maka dari ini pada bab ini akan diulas konsep Syariah produk pembiayaan jaminan sertifikat pendidik ini berdasarkan kajian pustaka ekonomi islam.

\section{Falsafah Pembiayaan}

Setiap lembaga keuangan syari'ah mempunyai falsafah mencari keridaan Allah swt. untuk memperoleh kebajikan di dunia dan akhirat. Oleh karena itu, setiap kegiatan lembaga keuangan yang dikhawatirkan menyimpang dari tuntunan agama harus dihindari. Berikut falsafah yang harus diterapkan oleh bank syari'ah dalam menjalankan operasionalnya:

1. Menjauhkan diri dari unsur riba, dengan cara: 
Isnawati, Muttaqillah, \& Siti Sofiyah: Konsep Syariah pada Pembiayaan Jaminan ...

a. Menghindari penggunaan sistem yang menetapkan di muka secara pasti

keberhasilan suatu usaha. Hal ini sesuai dengan firman Allah dalam Q.S.

Luqman [31]: 34:

Salah satu prinsip bagi hasil yang biasanya ditemukan dalam produk kerja sama seperti produk Mudarabah, Musyarakah dan Muzara'ah. Pada prinsip bagi hasil ini perbankan Syariah diharuskan menghindari system yang menetapkan di muka secara pasti keberhasilan suatu usaha. Sedangkan Produk pembiayaan dengan jaminan Sertifikat Pendidik pada Bank Pembiayaan Rakyat (BPR) $X$ ini mengelompokkannya ke dalam akun (fasilitas) Murabahah. Sebagaimana yag diketahui bahwa fasilitas Murabahah merupakan salah satu prinsip jual beli yang dijalankan untuk perekonomian Syariah yaitu akad jual beli barang tertentu. Dengan demikian dapat disimpulkan bahwa produk pembiayaan jaminan sertifikasi ini terhindar dari hal tersebut, yaitu tidak menetapkan di muka secara pasti keberhasilan suatu usaha.

b. Menghindari penggunaan sistem persentase untuk pembebanan biaya terhadap utang atau pemberian imbalan terhadap simpanan yang mengandung unsur melipatgandakan secara otomatis utang/simpanan tersebut hanya karena berjalannya waktu. Hal ini sebagaimana dijelaskan dalam Q.S. Ali Imran [3]: 130:

Psebagaimana yang dijelaskan sebelumnya bahwa produk pembiayaan dengan jaminan Sertifikat Pendidik pada Bank Pembiayaan Rakyat (BPR) X ini mengelompokkannya ke dalam akun (fasilitas) Murabahah. Sebagaimana yag diketahui bahwa fasilitas Murabahah merupakan salah satu prinsip jual beli yag dijalankan untuk perekonomian Syariah yaitu akad jual beli barang tertentu. Dalam transaksi jual tersebut, penjual harus menyebutkan dengan jelas barang yang diperjualbelikan, termasuk harga pembelian dan keuntungan yang diambil. 
Pada salah satu contoh yang diambil dalam penelitian ini adalah pembelian tanah sebanyak 2 are di lokasi $Y$ dengan harga Rp.100.000.000,-. Pembeli tanah katakanlah Bapak Z sudah membayar uang muka sebesar Rp.50.000.000 pada penjual tanah. Sehingga membutuhkan tambahan uang sebesar Rp.50.000.000 lagi untuk melunasi pembayaran tanah tersebut. Maka kebutuhan uang tersebut diperoleh dengan mengajukan ke BPR X tersebut. Singkat cerita, pengajuan Bapak Z direalisasi, dan tercatat pada akad persetujuan fasilitas bahwa BPR $X$ mencantumkn bahwa harga beli tanah tersebut sebesar Rp. 50.000.000,- dan menjual ke Bapak $Z$ dengan harga Rp.95.043.060,- dengan pembayaran system angsur selama 60 bulan.

Jika melihat kasus / contoh yang dijelaskan tersebut, maka dapat dikatakan bahwa produk ini tidak menggunakan system persentase untuk pembebanan biaya terhadap hutang. Adapaun system yang digunakan adalah system harga jual. Namun deminikian walaupun menggunakan system harga jual, namun jika dibandingkan dengan BPR konvensional, dimana pada BPR konvensional dengan produk yang sama yaitu kredit dengan jaminan sertifikat pendidik, memiliki nilai angsuran yang sama dengan BPR Syariah. Sehingga jika ditotal jumlah angsuran pada BPR konvensional dengan jumlah tahun yang sama dengan BPR syariah, maka akan memberikan total pembayaran yang sama dengan harga jual yang di tetapkan oleh BPR Syariah. Sehingga menimbulkan kekhwatiran bahwaproduk tersebut menggunakan persentase dalam penentuan harga jualnya. Adapun besaran persentase harga jualnya diduga mengacu pada besaran persentase pada BPR konvensional.

Namun dikarenakan kekhawatiran yang disebutkan di atas murni berdasarkan subjektifitas peneliti, tanpa melakukan penelitian lebih mendalam memeriksa metode penentuan / perhitungan harga jualnya, maka produk pembiayaan jaminan sertifikasi ini dapat disimpulkan sudah terhindar dari penggunaan system persentase untuk pembebanan biaya hutang nasabah. 
c. Menghindari penggunaan sistem perdagangan/penyewaan barang ribawi dengan imbalan barang ribawi lainnya dengan memperoleh kelebihan, baik kuantitas maupun kualitas.

Berdasarkan salah satu contoh kasus pembiayaan jaminan sertifikat pendidik yang diambil pada BPRS $X$ tersebut, maka dapat dinyatakan bahwa produk tersebut belum sepenuhnya mampu menghindari penggunaan system perdagangan/ penyewaan barang ribawi. Mengingat produk ini bisa diambil oleh nasabah umum, tanpa mengkhususkan Calon nasabahnya harus beragama islam dengan kata lain warga Indonesia yang non muslimpun memiliki kesempatan menjadi nasabah jenis pembiayaan ini.

Pada kenyataannya, meskipun jenis pembiayaan ini dikelompokkan dalam akun Murabahah, yaitu prinsip jual beli, pada saat calon nasabah bermaksud mengajukan untuk mengambil produk pembiayaan ini, dari pihak BPRS $X$ hanya menanyakan peruntukan kebutuhan uang tanpa melakukan pengecekan (survey) akan kebenaran pernyataan/informasi calon nasabah. Dan berdasarkan infornasi di awal dari calon nasabah tersebutlah dibuatkan perjanjian / akad Murabahah. Sehingga bisa saja bahwa peruntukan uang yang dipinjam tersebut untuk melakukan pembelian barang yang tidak halal menurut aturan islam atau barang riba lainnya.

d. Menghindari penggunaan sistem yang menetapkan di muka tambahan atas utang yang bukan atas prakarsa yang mempunyai utang secara sukarela. Menerapkan sistem bagi hasil dalam perdagangannya, dengan mengacu pada Q.S. al-Baqarah [2]: 275:

Karena produk pembiayaan jaminan sertifikat pendidik ini dikelompokkan ke dalam akun Murabahah, yaitu system jual beli 
barang dengan penggunaan harga jual di awal transaksi, maka produk ini bisa dikatakan terhindar dari penggunaan system yang menetapkan di muka tambahan atas utang yang bukan atas prakarsa yang mempunyai utang secara sukarela.

Dalam pelaksanaan pembiayaan, bank syari'ah harus memenuhi dua aspek yang sangat penting, yaitu:

a. Aspek syar'i, di mana dalam setiap realisasi pembiayaan. kepada para nasabah, bank syari'ah harus tetap berpedoman pada syari'ah Islam, antara lain tidak mengandung unsur maysir, garar, riba, serta bidang usahanya harus halal.

\section{- Unsur Maysir}

Terdapat ketidakjelasan pada produk pembiayaan jaminan sertifikasi ini yang dikelompokkan ke dalam akun Murabahah. Adapun ketidakjelasan yang ditemukan pada salah satu contoh akad pembiayaan tersebut antara lain:

- Barang yang diperjualbelikan tidak ditelusuri kejelasan keberadaannya, hanya mengandalkan informasi dari calon nasabah dan semua dituangkan pada butir-butir perjanjian akad.

Dalam salah satu butir akad dinyatakan bahwa sumber dana pembayaran angsuran hutang ini adalah dana tunjangan profesi / sertifikasi, yang mana dikatakan bahwa apabila karena suatu dan lain hal menyebabkan pembayaran tunjangan profesi/ Sertifikasi tertunda, atau dibatalkan, atau diberhentikan oleh Pemerintah atau sebab lainnya sehingga Nasabah tidak dapat membayar kewajibannya, maka nasabah wajib membayar seluruh kewajiban dengan sumber pendapatan lainnya atau menjual asset yang dimiliki guna

- Tidak danya barang yang cukup berharga untuk dijadikan jaminan, hanya berupa dokumen-dokumen nasabah berupa: 
- Sutrat Rekomendasi dari pimpinan nasabah tempat ia bekerja

- Asli buku tabungan, kartu ATM dan PIN tempat masuknya tunjangan profesi/sertifikasi

- Surat kuasa atau pengambilan atau penarikan tunjangan profesi/sertifikasi

- Asli sertifikat pendidik

Yang mana semua dokumen tersebut bisa dengan mudah digandakan seperti beberapa kasus yang dialami oleh BPRS X. setiap dokumen yang dijadikan jaminan tersebut bisa dikatakan bukanlah barang yang sangat berharga, mengingat:

- Surat rekomendasi dari pimpinan jelas bukan barang berharga yang bisa membuat nasabah berat untuk melakukan tindakan yang merugikan bank.

- Asli buku tanbungan, kartu ATM dan PIN tempat dana tunjangan profesi dicairkan bisa diganti dengan rekening yang lain.

- Asli sertifikat pendidik juga bukan merupakan surat berharga yang bisa diperjualbelikan. Dan sertifikat ini hanya sebagai bukti pihak pengajar sudah berhak mendapatkan uang tunjangan profesi. Dan biasanya dibutuhkan sebagai dokumen pelengkap. Tentunya pihak nasabah juga bisa memiliki salinannya berupa hasil fotokopi maupun hasil scan.

Setiap pembiayaan jelas memiliki risiko, namun dengan melihat fakta di atas tentulah pembiayaan jenis ini memiliki risiko yang sangat tinggi di saat perusahaan maupun perbankan berupaya mencari berbagai strategi untuk mengurangi atau memperkecil risiko. Dengan demikian dapat disimpulkan bahwa produk ini tidak dapat dipastikan secara $100 \%$ terhindar dari unsur Maysir.

- Unsur Gharar

Penjelasan sebelumnya menyatakan bahwa jenis pembiayaan ini sangat berisiko tinggi berdasarkan fakta yang terjadi. Melakukan transaksi Murabahah tanpa pengetahuan yang cukup jelas akan barang yang diperjualbelikan dikarenakan pihak BPRS $X$ tidak melakukan pengecekan terhadap barang yang diperjualbelikan. 
Dengan demikian, bisa dikatakan bahwa produk ini belum bisa dipastikan bebas dari unsur Gharar.

- Unsur Riba

Jika unsur riba didasarkan pada makna penggunaan prosentase untuk penentuan biaya modal, serta menentukan dimuka besaran dari biaya hutang yang diberikan pihak BPRS X ke nasabah, maka dapat dikatakan bahwa pihak bank terhindar dari unsur riba untuk produk pembiayaan jaminan sertifikasi ini.

- Unsur Halal

Salah satu syarat sahnya jual beli yaitu barang yang diperjualbelikan jelas keberadaannya. Namun pihak Bank tidak pernah mengecek kejelasan barang yang diperjualbelikan. Jika melihat fakta yang ada, maka transaksi seperti ini masih dipertanyakan unsur kehalalannya.

b. Aspek ekonomi, yakni dengan tetap mempertimbangkan . perolehan keuntungan, baik bagi bank syari'ah maupun bagi nasabah bank syari'ah.

Produk ini memiliki unsur untung rugi bagi kedua belah pihak, yaitu pihak nasabah maupun pihak BPRS $X$. keuntungannya meliputi:

- Pihak nasabah jelas diuntungkan dengan adanya pembiayaan ini, karena bisa mengatasi masalah keungannya.

- Pihak Bank tentunya juga diuntungkan dengan produk pembiayaan ini berupa keuntungan dari transaksi Murabahah.

Mengacu pada contoh transaksi Tuan $\mathrm{Z}$, maka produk ini juga memberikan kerugian bagi pihak Nasabah maupun pihak Bank, yaitu:

- Perhitungan harga beli barang oleh pihak bank yang dibebankan ke nasabah tidak jelas. Dan hanya menguntungkan pihak bank saja. Mengingat tanah seluas 2 are dengan harga Rp.100.000.000 dihargai Rp. 50.000.000 oleh pihak BPRS X, dimana tanah itu dijual kembali ke nasabah seharga hampir Rp. 100.000.000,- 


\section{Prinsip-prinsip Pembiayaan}

Salah satu prinsip pembiayaan bagi bank Syariah adalah prinsip jual beli.

Prinsip ini terdapat dalam produk:

b.1. Bai' al-Murabahah, yaitu akad jual beli barang tertentu. Dalam transaksi jual beli tersebut, penjual menyebutkan dengan jelas barang yang diperjualbelikan, termasuk harga pembelian dan keuntungan yang diambil.

b.2. Bai' al-muqayyadah, yaitu jual beli di mana pertukaran terjadi antara barang dengan barang (barter). Aplikasi jual beli semacam ini dapat dilakukan sebagai jalan keluar bagi transaksi ekspor yang tidak dapat menghasilkan valuta asing (devisa).

b.3. Bai' al-mutlaqah, yaitu pertukaran antara barang atau jasa dengan uang. Uang berperan sebagai alat tukar. Jual beli semacam ini menjiwai semua produk lembaga keuangan yang didasarkan atas prinsip jual beli.

b.4. Bai' as-salam, yaitu akad jual beli di mana pembeli membayar uang (sebesar harga) atas barang yang telah disebutkan spesifikasinya, sedangkan barang yang diperjualbelikan itu akan diserahkan kemudian, yaitu pada tanggal yang disepakati. 
b.5. Bai' al-istisna. yaitu kontrak jual beli di mana harga atas barang tersebut dibayar lebih dulu, tetapi dapat diangsur sesuai dengan jadwal dan syarat-syarat yang disepakati bersama, sedangkan barang yang dibeli diproduksi dan diserahkan kemudian.

Penjelasan di atas menyatakn bahwa prinsip jual ini merupakan suatu sistem yang menerapkan tata cara jual beli, di mana bank akan membeli terlebih dahulu barang yang dibutuhkan atau mengangkat nasabah sebagai agen bank melakukan pembelian barang atas nama bank, kemudian bank menjual barang tersebut kepada nasabah dengan harga sejumlah harga beli ditambah keuntungan (margin/mark-up). Jika kita kembali ke salah satu contoh akad yang terjadi pada Bapak Z, maka akad Murabahah yang disematkan ke produk pembiayaan dengan Jaminan sertifikasi. Mengingat transaksi jual beli pada akad tersebut masihlah belum jelas. Hal ini dikarenakan beberapa hal antara lain:

- Barang yang dperjualbelikan adalah berupa tanah seluas 2 are dengan harga beli oleh Nasabah ke penjual tanah seharga Rp.100.000.000 untuk yang 2 are tersebut, dengan kata lain Rp.50.000.000 per are. Calon Nasabah sudah membayar setengah dari harga ke penjual tanah, sehingga tersisa Rp.50.000.000 untuk pelunasan. Dan sumber pendanaan untuk pelunasan ini bersumber dari pembiayaan dari BPRS $X$ dengan jaminan sertifikasi. Namun pada akad Murabahah tertulis bahwa peruntukan pembiayaan adalah pembelian tanah seluas 2 are dengan harga beli Rp.50.000.000 dan dijual kembali ke calon Nasabah seharga Rp. 98.000.000,-.. Dengan demikian dapat dikatakan bahwa dasar penentuan harga beli oleh BPRS $X$ sangatlah tidak jelas. Dan konsdisi ini akan menguntungkan bagi pihak BPRS $X$, namun akan merugikan bagi pihak Nasabah.

- Barang yang diperjualbelikan haruslah jelas, namun pada kenyataannya pihak BPRS X tidak melakukan survey lapangan untuk memastikan barang yang diperjualbelikan. Dengan demikian Barang yang diperjualbelikan masih jauh dari unsur kejelasan. 
Isnawati, Muttaqillah, \& Siti Sofiyah: Konsep Syariah pada Pembiayaan Jaminan ...

Dampak Pembiayaan Jaminan Sertifikat Pendidik Terhadap Risiko Kredit (Pembiayaan) pada BPRS X di Kota Mataram

\section{Tabel 3.}

Perkembangan Akun Murabahah pada BPRS X Tahun 2011 s/d 2017

\begin{tabular}{|c|c|c|c|}
\hline Tahun & Murabahah & Peningkatan & $\begin{array}{l}\text { Rata- } \\
\text { Rata }\end{array}$ \\
\hline 2017 & $186,231,951$ & 0.82 & 0.82 \\
\hline 2016 & $102,219,552$ & 0.16 & \multirow{2}{*}{0.22} \\
\hline 2015 & $88,482,653$ & 0.34 & \\
\hline 2014 & $66,247,409$ & 0.25 & \multirow{2}{*}{0.13} \\
\cline { 1 - 2 } 2013 & $53,128,196$ & 0.13 & \\
\hline 2012 & $46,874,384$ & 0.22 & \\
\hline 2011 & $38,290,772$ & - & \\
\hline
\end{tabular}

Sumber: Data diolah

Jika dilihat pada Tabel 3 di atas, maka sangat terlihat jelas bahwa nilai akun

Murabahah dari tahun 2011 hingga tahun 2016 tidak begitu menunjukkan perkembangan yang signifikan, namun pada tahun 2017 nilai akun ini meningkat sangat drastis dari tahun 2016. Peningkatan yang begitu drastis ini bisa jadi dikarenakan adanya produk pemiayaan dengan jaminan sertifikat pendidik. Angka peningkatan yang sangat signifikan ini tentunya menjadi berita baik sekaligus berita buruk bagi perbankan. Berita baiknya yaitu pihak perbankan memiliki kesempatan yang besar untuk perolehan keuntungan yang juga besar, namun perlu diingat bahwa teori risiko menyatakan bahwa tingkat keuntungan berbanding lurus dengan tingkat risiko yang ditanggung. Dan hal itulah yang menjadi berita buruk bagi perbankan. 
Adapun perkembangan risiko kredit yang ada pada BPRS $\mathrm{X}$ dari tahun 2011 sampai dengan tahun 2017 dapat dilihat pada table 4.1. Berdasarkan tabel 4.1. di atas digambarkan bahwa risiko pembiayaan (kredit) pada BPRS X tergolong rendah, karena rata-rata nilai NPLnya kurang dari 5\%. Dimana angka ini menunjukkan bahwa risiko akan pembiayaan bermasalahnya terbilang cukup rendah. Walaupun sejak dikeluarkannya produk pembiayaan jaminan sertifikasi ini pada tahun 2016, nilai NPL meningkat pada tahun 2017. Akan tetapi angka NPL pada tahun 2017 juga tergolong rendah karena kurang dari $5 \%$ dan peningkatannyapun juga tidak signifikan pada angka $0.05 \%$ dari tahun 2011 hingga tahun 2016 yang rata-rata memiliki nilai NPL sebesar $0.87 \%$.

Tentunya fakta ini tidak berhasil membuktikan bahwa tingkat pendapatan yang tinggi akan diikuti oleh tingkat risiko yang tinggi pula. Dan untuk pembiayaan Murabahah yang mengalami peningkatan yang cukup drastis pada tahun 2017 sejak dikeluarkannya produk pembiayaan dengan jaminan sertifikasi ternyata tidak membuat nilai NPL BPRS X meningkat drastis. Hal ini bisa jadi dikarenakan pihak BPRS X memiliki strategi yang cukup memadai dalam meminimalkan risiko perbankan khususnya risiko pembiayaan (kredit) yang diperlihatkan dengan angka NPL yang cukup rendah. 
$\underline{\text { Isnawati, Muttaqillah, E Siti Sofiyah : Konsep Syariah pada Pembiayaan Jaminan ... }}$

\section{SIMPULAN}

Hasil penelitian menjelaskan bahwa masih terdapat ketidak jelasan konsep Syariah pada produk pembiayaan dengan jaminan sertifikat pendidik. Karena produk perbankan Syariah harus tetap berpedoman pada syari'ah Islam, antara lain tidak mengandung unsur maysir, Gharar, riba, serta bidang usahanya harus halal. Jika menelusuri pada salah satu bukti yang ada dan berdasarkan hasil observasi peneliti, maka dapat disimpulkan bahwa produk ini sudah sepenuhnya memuat konsep Syariah, karena produk ini belum mampu terhindar dari unsur maysir, ghrarar secara 100\%, maupun unsur kehalalan transaksinya masih diragukan. Jenis produk ini bisa dikatakan memiliki tingkat risiko yang tinggi jika melihat mekanisme pembiayaannya, namun berdasarkan data NPL yang dimiliki BPRS $X$ tersebut, tidak berhasil membuktikan bahwa tingkat pendapatan yang tinggi akan diikuti oleh tingkat risiko yang tinggi pula.

\section{DAFTAR PUSTAKA}

Al Quran

As-Sunnah 
Alamsyah, Halim, "Perkembangan dan Prospek Perbankan Syariah Indonesia: Tantangan Dalam Menyongsong MEA2015", Makalah yang disampaikan dalam Ceramah Ilmiah Ikatan Ahli Ekonomi Islam (IAEI), Milad ke-8, Jakarta, 2012.

Anshori, Abdul Ghofur, Perbankan Syariah di Indonesia, Yogyakarta: Gadjah Mada University Press, 2007.

Antonio, Muhammad Syafi'i, Bank Syariah: Dari Teori ke Praktik, Jakarta: Gema Insani Press, 2001.

Arifin, Zainul, Konsep Operasional Bank Syariah, Jakarta: Rafa Consulting.

Bank Indonesia (2012). Kodifikasi Peraturan Bank Indonesia, Liabilitas dan Modal, Pelaksanaan prinsip Syariah dalam Kegiatan Penghimpunan dan penyaluran Dana Serta Pelayanan Jasa Bank Syariah, Produk Bank Syariah dan Unit Usaha Syariah. Pusat Riset dan Edukasi Bank Sentra (PRES) Bank Indonesia.

Bank Indonesia, Statistik Perbankan Syariah - Agustus 2013, Jakarta: Bank Indonesia, 2013.

Baraba, Ahmad, Prinsip Dasar Operasional Perbankan Syariah, Jakarta: Bank Indonesia, 1999. 
Isnawati, Muttaqillah, \& Siti Sofiyah: Konsep Syariah pada Pembiayaan Jaminan ...

Farida dan Dewi,Veni Soraya (2016). The Analysis Of Risk Management On Syariah Banking In Idonesia. Syariah Paper Accounting FEB UMS, ISSN 2460-0784. Universitas Muhammadiyah Magelang.

Fitri, Maltuf (2015). Prinsip Kesyariahan Dalam Pembiayaan Syariah. Economica, Volume VI/Edisi 1/Mei 2015. Indonesia.

Ilyas, Rahmat (2015). KOnsep Pembiayaan Dalam Perbankan Syariah. Jurnal

Penelitian, Vol.9, No.1, Februari 2015. STAIN Syaikh Abdurrahman Siddik Banka Belitung.

Mu'allim, Amir (2004). Praktek Pembiayaan Bank Syariah Dan Problematikanya. Al-Mawarid Edisi XI 2004. Fakultas Ilmu Agama Islam Universitas Islam Indonesia (UII) Yogyakarta.

Muhammad, Danang Wahyu (2014). Penerapan Prinsip Syariah Dalam Permodalan Bank Syariah. Jurnal Media Hukum. Universitas Muhammadiyah Yogyakarta.

Otoritas Jasa Keuangan (OJK) Dan Industri Jasa Keuangan (2016). Industri Jasa Keuangan Syariah. www.ojk.go.id. Diunduh pada tanggal 28 Februanri 2018 pukul 21:10 WITA.

Peraturan Bank Indonesia nomor: 11/3/PBI2009 tentang bankumum syariah Surat edaran bank Indonesia nomor: 11/9/DPbS tanggal 7 April 2009 tentang bank umum syariah. 
Peraturan Bank Indonesia Nomor 12/7/PBI/2010 Tentang Perubahan Atas Peraturan Bank Indonesia Nomor 11/19/PBI/2009 Tantang Sertifikasi Manajemen Risiko Bagi Pengurus dan Pejabat Bank Umum.

Peraturan Bank Indonesia Nomor: 6/24/PBI/2004 tentang Bank Umum yang Melaksanakan Kegiatan Usaha Berdasarkan Prinsip Syariah Sebagaimana telah diubah dengan Peraturan Bank Indonesia No: 7/35/PBI/2005.

Peraturan Bank Indonesia Nomor: 8/26/PBI/2006 tentang Bank Perkreditan Rakyat.

Peraturan Bank Indonesia Nomor: 8/3/Pbi/2006 tentang perubahan keiatan usaha bank umum konvensional menjadi bank umum yang melaksanakan kegiatan usaha berdasarkan prinsip syariah dan pembukaan kantor bank yang melaksanakan kegoatan usaha berdasarkan prinsip syariah oleh bank umum konvensional.

Peraturan Bank Indonesia Nomor:7/46/PBI/2005 tentang Akad Penghimpunan Dan Penyaluran Dana Bagi Bank Yang Melaksanakan kegiatan Usaha berdasarkan Prinsip Syariah.

Peraturan Bank Indonesia Noor 13/23/PBI/2011 tentang Penerapan Manajemen Risiko Bagi Bank Umum Syariah Dan Unit Usaha Syariah. 
Isnawati, Muttaqillah, $\mathcal{E}$ Siti Sofiyah : Konsep Syariah pada Pembiayaan Jaminan ...

Peraturan Bank Indonesia. Nomor 18/40/PBI/2016 tentang Penyelenggaraan Pemrosesan Transaksi Pembayaran.

Peraturan Jasa Keuangan Nomor 65/POJK.03/2016 Tentang Penerapan Manajemen Risiko Bagi bank Umum Syariah Dan Unit Usaha Syariah.

Puspitaningsih, Dewi, "Analisis Aplikasi Prinsip-Prinsip Perbankan Syariah Terhadap Aspek Penghimpunan Dana dan Aspek Penyaluran Dana (Studi Kasus Pada Bank Muamalat Indonesia Cabang Malang)", Skrispsi, Malang: Fakultas Ekonomi Universitas Malang, 2010.

SK Direksi Bank Indonesia Nomor: 32/34/KEP/DIR tanggal 12 Mei 1999 tentang Bank Umum Berdasarkan Prinsip Syariah. 